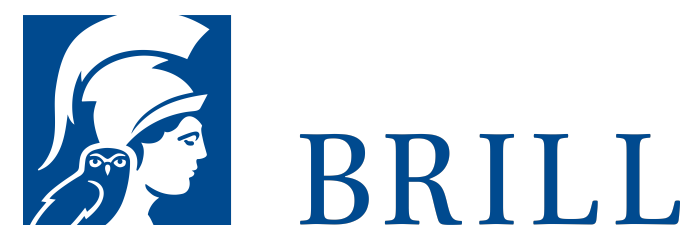

\title{
Die Politische Theorie in der Neuen Musik
}

\author{
Karl Amadeus Hartmann und Hannah Arendt \\ Author: Raphael Woebs
}

Der Begriff des »Politischen« scheint in der sogenannten »Postmoderne « endgültig sämtlicher aristotelischen Ursprünge verlustig und pejorativ auf ein niedrigstes Niveau einer vornehmlich negativ besetzen »Parteien-« respektive »Tagespolitik« reduziert. Demgegenüber steht das auf eine handlungsorientierte Öffentlichkeit abzielende Politikverständnis bei Hannah Arendt, die - an aristotelische Traditionen anknüpfend - den Begriff der Freiheit (zu handeln) ausschließlich im politischen Bereich lokalisiert, entsprechend also das Handeln in Freiheit als »politische Fähigkeit par excellence « nobilitiert und damit in ihren politischen Schriften zugleich komplementär eine ästhetische Theorie der »Inneren Emigration«mitdenkt. So bemühte sich der Komponist der Inneren Emigration Karl Amadeus Hartmann zum einen unmittelbar nach Kriegsende im Rahmen der von ihm initiierten und bis heute beispielgebenden Konzertreihe »Musica viva« erfolgreich um eine größtmögliche Öffentlichkeit für während der NS-Zeit als »entartet« verfemte Werke und Komponisten. Zum anderen charakterisieren insbesondere die zwischen 1933 und 1945 - also der Zeit des künstlerisch-politischen »Schweigens« im Sinne Sartres - komponierten Werke Hartmanns seinen unbändigen und vor allem ununterbrochenen Drang hin zur »Agora «. In seinem letzten Werk Gesangsszene (1963) entwirft der Komponist schließlich... See More

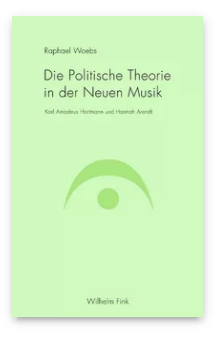

Pages: 161 Seiten, $1 \mathrm{~s} / \mathrm{w}$

Abb.

Language:

German

Subjects:

General,

Musicology

Publisher: Brill |

Fink

E-Book (PDF)

Released online:

og Dec 2019

ISBN: $978-3-$

8467-4936-4

List price

USD $\$ 48.00$

Paperback

Publication date: 16 Jun 2010

ISBN: $978-3-$

7705-4936-8

List price

USD $\$ 48.00$ 
For more information see brill.com

Order information: Order online at brill.com +44330 333 0049 | customerservices@brill.com Submission information: brill.com/authors

Titles published by Brill | Fink, Brill | mentis or Brill | Schöningh: +49(o)715413279216| brill@brocom.de 